\title{
Long term variations of river temperature and the influence of air temperature and river discharge: case study of Kupa River watershed in Croatia
}

\author{
Senlin $\mathrm{Zhu}^{1}$, Ognjen Bonacci ${ }^{2}$, Dijana Oskoruš ${ }^{3}$, Marijana Hadzima-Nyarko ${ }^{4 *}$, Shiqiang $\mathrm{Wu}^{1}$ \\ ${ }^{1}$ State Key Laboratory of Hydrology-Water resources and Hydraulic Engineering, Nanjing Hydraulic Research Institute, Nanjing 210029, \\ China. \\ ${ }^{2}$ Faculty of Civil Engineering and Architecture, University of Split, Matice hrvatske 15, 21000 Split, Croatia. \\ ${ }^{3}$ Meteorological and Hydrological Service, Gric 3, 10000 Zagreb, Croatia. \\ ${ }^{4}$ Josip Juraj Strossmayer University of Osijek, Faculty of Civil Engineering and Architecture Osijek, Vladimira Preloga 3, 31000 Osijek, \\ Croatia. \\ ${ }^{*}$ Corresponding author. E-mail: mhadzima@gfos.hr
}

\begin{abstract}
The bio-chemical and physical characteristics of a river are directly affected by water temperature, which therefore affects the overall health of aquatic ecosystems. In this study, long term variations of river water temperatures (RWT) in Kupa River watershed, Croatia were investigated. It is shown that the RWT in the studied river stations increased about $0.0232-0.0796^{\circ} \mathrm{C}$ per year, which are comparable with long term observations reported for rivers in other regions, indicating an apparent warming trend. RWT rises during the past 20 years have not been constant for different periods of the year, and the contrasts between stations regarding RWT increases vary seasonally. Additionally, multilayer perceptron neural network models (MLPNN) and adaptive neuro-fuzzy inference systems (ANFIS) models were implemented to simulate daily RWT, using air temperature $\left(T_{a}\right)$, flow discharge $(Q)$ and the day of year $(D O Y)$ as predictors. Results showed that compared to the individual variable alone with $T_{a}$ as input, combining $T_{a}$ and $Q$ in the MLPNN and ANFIS models explained temporal variations of daily RWT more accurately. The best accuracy was achieved when the three inputs $\left(T_{a}, Q\right.$ and the $\left.D O Y\right)$ were included as predictors. Modeling results indicate that the developed models can well reproduce the seasonal dynamics of RWT in each river, and the models may be used for future projections of RWT by coupling with regional climate models.
\end{abstract}

Keywords: Climate change; Machine learning models; River water temperature.

\section{INTRODUCTION}

River water temperature (RWT) is one of the most important indicators to determine the overall health of aquatic ecosystems since it affects various physical and biochemical processes in rivers (Rice and Jastram, 2015). For example, RWT significantly impacts dissolved oxygen dynamics (Cox and Whitehead, 2009), the formation of potentially toxic ammonia (Kim et al., 2017), and the evolution and distribution of aquatic organisms (Fullerton et al., 2018). Cingi et al. (2010) stressed that relatively small increases in RWT during the spawning period of Coregonus lavaretus may lead to fatal impacts on its recruitment and population persistence.

Understanding the factors impacting RWT and how thermal regimes have changed in the past and how they can be modified in the future is therefore of great significance for the sustainable management of river ecosystems. This is especially important in recent decades considering the rising of air temperatures due to climate change (van Vliet et al., 2013), the impacts of extreme climate events such as heatwaves (Feng et al., 2018; Schär et al., 2004) and anthropogenic activities such as land use change (DeWeber and Wagner, 2014; LeBlanc et al., 1997), urbanization (DeWeber and Wagner, 2014; Chen et al., 2016) and damming (Ayllón et al., 2012). Rising RWT is strongly related to climate warming with various time scales for different type of rivers, which have been reported in a lot of studies (Bonacci et al., 2008; Chen et al., 2016; Gooseff et al., 2005; Null et al., 2013; Webb et al., 2003). For example, Chen et al. (2016) indicated that RWT in the Yongan watershed increased by $0.029-0.046^{\circ} \mathrm{C}$ year ${ }^{-1}$ due to a $\sim 0.050^{\circ} \mathrm{C}$ year $^{-1}$ increase of air temperature over the 1980-2012 period.
Although the air-water temperature relationship is generally strong, the strength of such a relationship varies regionally and temporally, and can be highly site specific due to additional influences from local hydrology and human activities (DeWeber and Wagner, 2014; Zhu et al., 2019). It is commonly observed that RWT is inversely related to river discharge, and a global assessment indicated that a decrease in river discharge by $20 \%$ and $40 \%$ would exacerbate water temperature increases by $0.3^{\circ} \mathrm{C}$ and $0.8^{\circ} \mathrm{C}$ on average, respectively (van Vliet et al., 2011). Additionally, it was found that river discharge played a relevant role mainly in snow-fed and regulated rivers with higher altitude hydropower reservoirs, while it played a minor role in lowland rivers for RWT dynamics (Zhu et al., 2019). Depending on the river type and time scale, the air-water temperature relationships can be explained by linear or logistic functions (Hadzima-Nyarko et al., 2014; Webb et al., 2003), machine learning models (DeWeber and Wagner, 2014; Hadzima-Nyarko et al., 2014; Piotrowski et al., 2015; Zhu et al., 2019), and hybrid statistically and physically based models (Toffolon and Piccolroaz, 2015).

Kupa River watershed is one of the most important water resources in Croatia, and quantifying thermal dynamics in this particular river catchment is thus of great significance to water resources managers. Previously, Bonacci et al. (2008) analyzed water temperature regime of the Danube and its tributaries in Croatia, including the main stem of the Kupa River. However, the RWT data from the main stem hydrological stations were only limited to 1951-2003. In this study, the latest RWT and flow discharge data from 6 hydrological stations on the main tributaries of Kupa River were evaluated to describe and identify changes in the thermal regime of the watershed. In addition, 
we developed predictive water temperature models using the multilayer perceptron neural network (MLPNN) and adaptive neuro-fuzzy inference system (ANFIS) machine learning tools following their use by Zhu et al. (2019) for the Drava River. In the Drava River model (Zhu et al., 2019), the components of the Gregorian calendar $(C G C)$ which include year, month, and day were used as suggested by Heddam (2016) and Heddam and Kisi (2017) for water quality modelling. For RWT forecasting, the day of year (DOY) was used in the forwards and backwards stepwise model for Scotland's Atlantic salmon rivers (Jackson et al., 2018). In this study, air temperature, river discharge, and DOY were used as inputs to predict RWT. The objective of this study is to analyze thermal regimes of rivers in the Kupa River watershed, develop models which can be used for future RWT projections and further test the performance of MPLNN and ANFIS for predicting water temperatures under different hydrologic conditions than those of Zhu et al. (2019).

\section{MATERIALS AND METHODS Study area}

The study covers the Kupa River basin, situated between Croatia $(86 \%$ of total basin area) and Slovenia $(14 \%$ of total basin area) in the hinterland of the Northern Adriatic Sea (Fig. 1). The region is characterized by complex karst hydrological/hydrogeological behavior common to the deep and developed Croatian Dinaric karst, resulting in a weakly defined hydrological drainage area (Bonacci and Andrić, 2010). A mix of continental and Mediterranean climate influences the upper part of the basin, while Pannonian climate is the most important in the lower part. The patterns of land use in the Kupa River basin include mountains (26\%), forests $(33 \%)$, pasture $(26 \%)$ and agriculture (15\%) (Frančišković-Bilinski et al., 2012). Hydrological parameters (water temperature and river discharge) were regularly monitored at six gauging stations in the Kupa River selected for this study. Table 1 presents the main characteristics of the 6 studied gauging stations (station name, station elevation, drainage area, period of available data for water temperature and flow discharge). River water temperature data was monitored once-daily at 7.30 am. Daily river discharge was calculated based on measurements of water level using the water level-river discharge RK method. Daily average air temperatures $\left(T_{a}\right)$ were obtained from the nearby meteorological station in Ogulin for 1990-2017.

\section{Analysis methods}

In this study, annual variations of $T_{a}$ and $T_{w}$ in each river station were analyzed using linear models with year as effect for trend analysis. The correlations between the RWT increase rates and annual averaged flow discharges, and relationships between the mean annual RWT and the station elevation for the six river stations were investigated using linear models. Changes in $T_{a}, T_{w}$ and $Q$ for annual and seasonal average values were compared between five years averages for two sub-periods (1996-2000 and 2011-2015). Since the Čabranka River only has data till 2008, data from 1990-1994 and 2004-2008 was compared. The seasonal dynamics of $T_{w}, T_{a}$ and $Q$ are analyzed through the climatological year, which is defined by averaging for each day of the calendar year all measurements available over the observation period for that same specific day (Zhu et al., 2019).

Table 1. Main characteristics of the 6 studied water temperature gauging stations in the Kupa River watershed.

\begin{tabular}{|c|c|c|c|c|c|c|}
\hline \multirow[t]{2}{*}{ River name } & \multirow[t]{2}{*}{ Station name } & \multirow{2}{*}{$\begin{array}{l}\text { Elevation } \\
\text { (m a.s.l.) }\end{array}$} & \multirow{2}{*}{$\begin{array}{c}\text { Drainage area } \\
\left(\mathrm{km}^{2}\right)\end{array}$} & \multirow[t]{2}{*}{ Period of available data } & \multicolumn{2}{|c|}{ Long term averages } \\
\hline & & & & & $T_{w}$ & $Q$ \\
\hline Čabranka & Zamost 2 & 297.540 & $134.451^{\mathrm{a}}$ & $T_{w} Q: 1990-19992002-2008$ & 8.14 & 3.50 \\
\hline Donja Dobra & Stative Donje & 116.456 & $49.344^{\mathrm{a}}$ & $T_{w} Q: 1994-2017$ & 12.34 & 37.28 \\
\hline Donja Mrežnica & Mrzlo Polje & 113.967 & $257.953^{\mathrm{a}}$ & $T_{w} Q: 1990-2017$ & 13.80 & 26.14 \\
\hline Gornja Dobra & Luke & 353.668 & $162.00^{\mathrm{b}}$ & $T_{w} Q: 1991-19921994-2015$ & 9.01 & 6.78 \\
\hline Korana & Slunj Uzvodni & 212.167 & $572.341^{\mathrm{a}}$ & $T_{w} Q: 1996-20042007-2017$ & 12.41 & 9.97 \\
\hline Slunjčica & Rastoke & 226.899 & $273.00^{\mathrm{b}}$ & $T_{w} Q: 1996-2017$ & 10.78 & 8.32 \\
\hline
\end{tabular}

$T_{w}$ : water temperature; $Q$ : flow discharge; a Hydrological drainage area, b Topographical drainage area

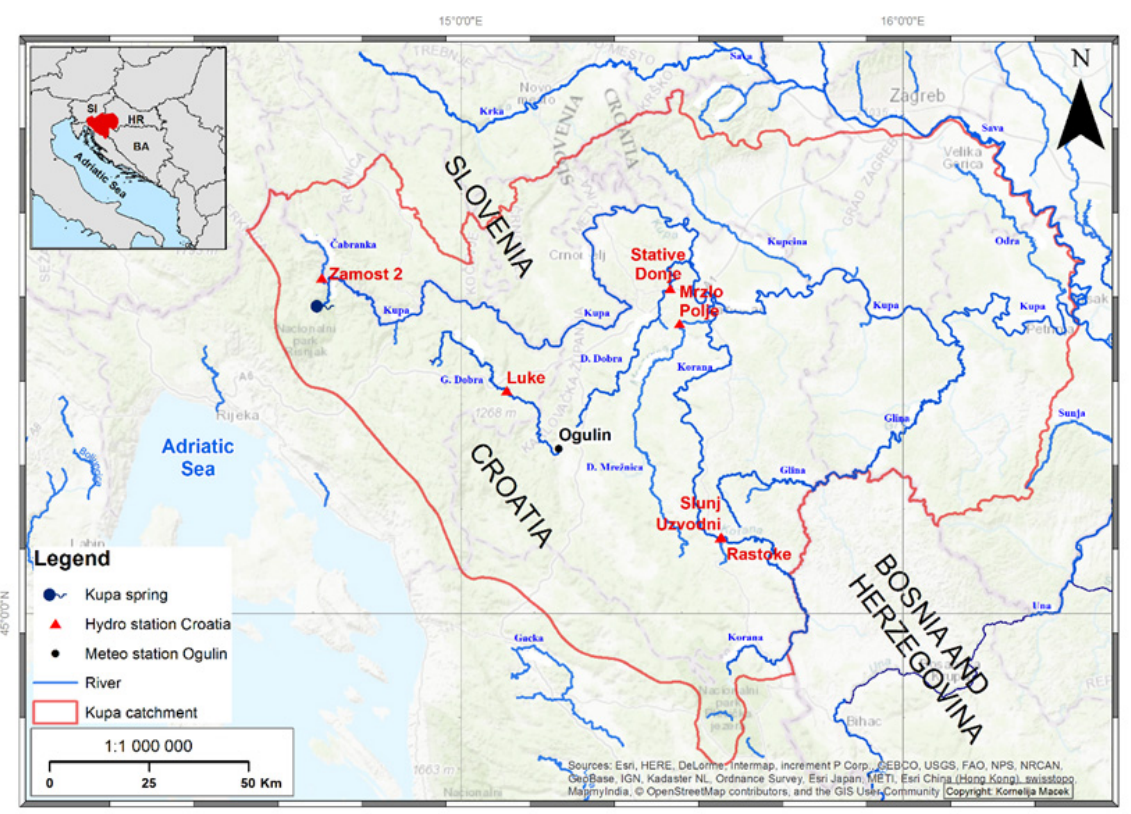

Fig. 1. Location map indicating the studied river catchment. 


\section{Machine learning models}

In the present study, the MLPNN and ANFIS models applied previously by Zhu et al. (2019) were used. For the MLPNN model, the weights $\left(w_{i j}\right)$ and bias levels $\left(\delta_{0}\right)$ are the only parameters that need to be adjusted when the structure of the neural network has been defined (number of layers, number of neurons in each layer, activation function for each layer). Modification of these parameters will change the output values of the designed network. The weights $\left(w_{i j}\right)$ and bias levels $\left(\delta_{0}\right)$ are iteratively adjusted during model training to minimize error. The root mean squared error (RMSE) and the mean squared error (MSE) is often used to define the network error. Similar to Zhu et al. (2019), the MLPNN model has one hidden layer with sigmoidal activation function, and one output layer with linear activation function. We tried to vary the number of neurons in the hidden layer from 10 and 13 , and it was found that there is no any significant improvement for model performance, thus, the number of neurons in the hidden layer is set as 10 . To develop ANFIS model, it is important to create the fuzzy rule base. The number of fuzzy rule for any ANFIS model is directly related to the identification method used for partitioning the input space. According to the previous research results (Zhu et al., 2019), the fuzzy c-means clustering (FC) was used. When using FC method, the number of fuzzy rules is equal to the clusters and fixed by the user. Detailed information about the two models can be found in Zhu et al. (2019).

In this study, both the scripts of the MLPNN and ANFIS models were implemented in Matlab.

Besides air temperature $\left(T_{a}\right)$ and flow discharge $(Q)$, the day of the year $(D O Y)$ was also used as input variable. Three MLPNN and three ANFIS models were developed with the following predictors: (i) version 1 with only one input variable $\left(T_{a}\right)$, (ii) version 2 with two inputs variable $\left(T_{a}\right.$ and $Q$ ) and (iii) version 3 with three inputs $\left(T_{a}, Q\right.$ and the $\left.D O Y\right)$. For the six river stations, data period for model training and testing are respectively: (1) 1990-1999 and 2002-2008 for Čabranka River, (2) 1994-2009 and 2010-2017 for Donja Dobra River, (3) 1990-2007 and 2008-2017 for Donja Mrežnica River, (4) 1991-1992 plus1994-2007 and 2008-2015 for Gornja Dobra River, (5) 1996-2004 plus 2008-2010 and 2011-2017 for Korana River, and (6) 1996-2009 and 2010-2017 for Slunjčica River.

\section{Model evaluation metrics}

Model performances were evaluated using the following four indicators: the coefficient of correlation (R), the Willmott index of agreement (d), the root mean squared error (RMSE), and the mean absolute error (MAE).

$$
\begin{aligned}
& R=\left[\frac{\frac{1}{n} \sum_{i=1}^{n}\left(O_{i}-O_{m}\right)\left(P_{i}-P_{m}\right)}{\sqrt{\frac{1}{n} \sum_{i=1}^{n}\left(O_{i}-O_{m}\right)^{2}} \sqrt{\frac{1}{n} \sum_{i=1}^{n}\left(P_{i}-P_{m}\right)^{2}}}\right] \\
& d=1-\frac{\sum_{i=1}^{n}\left(P_{i}-O_{i}\right)^{2}}{\sum_{i=1}^{n}\left(\left|P_{i}-O_{m}\right|+\left|O_{i}-O_{m}\right|\right)^{2}} \\
& R M S E=\sqrt{\frac{1}{n} \sum_{i=1}^{n}\left(O_{i}-P_{i}\right)^{2}}
\end{aligned}
$$

$$
M A E=\frac{1}{n} \sum_{i=1}^{n}\left|O_{i}-P_{i}\right|
$$

where $n$ is the number of data samples, $O_{i}$ is the observed and $P_{i}$ is the predicted water temperatures. $O_{m}$ and $P_{m}$ are the average values of $O_{i}$ and $P_{i}$.

\section{RESULTS AND DISCUSSION Dynamic variations of water temperature and air temperature}

The annual variations of $T_{a}$ and $T_{w}$ are presented in Fig. 2 . Air temperatures increased about $0.0449^{\circ} \mathrm{C}_{\text {year }}{ }^{-1}$, while RWT increases differed between the studied river stations from $0.0232-0.0796^{\circ} \mathrm{C}$ per year. The RWT increase rate $\left({ }^{\circ} \mathrm{C}\right.$ year $\left.{ }^{-1}\right)$ negatively correlated with annual averaged flow discharge (Fig. 3 ). The observed RWT increases are comparable with long term observations reported for rivers in China $\left(0.029-0.046^{\circ} \mathrm{C}\right.$ year ${ }^{-1}$, Chen et al. 2016), USA $\left(0.009-0.077^{\circ} \mathrm{C}\right.$ year ${ }^{-1}$, Isaak et al., 2012; van Vliet et al., 2013; Rice and Jastram, 2015) and Europe $\left(0.006-0.18^{\circ} \mathrm{C}\right.$ year $^{-1}$, Albek and Albek, 2009; Hardenbicker et al., 2017; Lepori et al., 2014; Markovic et al., 2013; Moatar and Gailhard, 2006; Orr et al., 2015; Pekárová et al., 2011; Žganec, 2012).

Fig. 4 presents changes in $T_{a}, T_{w}$ and $Q$ for annual and seasonal average values. For all the rivers, annual averaged $T_{a}, T_{w}$ and $Q$ increased during the two sub-periods (1996-2000 and 2011-2015) except for the decreased $Q$ in the Slunjcica River. With an increase of $0.94^{\circ} \mathrm{C}$ for air temperature, the annual mean of RWT increased about $0.146-1.287^{\circ} \mathrm{C}$. Increases in annual mean RWT was highest for the Korana River $\left(1.287^{\circ} \mathrm{C}\right)$ and least for the Donja Dobra River $\left(0.146^{\circ} \mathrm{C}\right)$. Repeating this analysis for different seasonal quarters revealed that RWT rises during the two sub-periods have not been constant for different periods of the year, and the contrasts between river stations regarding RWT increases vary seasonally. For the Čabranka river (Fig. 4(a)), though air temperature in January-March and July-September decreased, RWT in different seasons still increased between 0.386 and $0.878^{\circ} \mathrm{C}$. For the other five rivers, the greatest rises in average RWT ranged from 0.626 to $5.221^{\circ} \mathrm{C}$. Particularly, RWT increases in July-September exceeded $5.0^{\circ} \mathrm{C}$ and $2.0^{\circ} \mathrm{C}$ for the Korana River (Fig. 4(e)) and the Gornja Dobra River (Fig. 4(d)) respectively.

Fig. 5 presents a linear relationship between the mean annual RWT and the station elevation for the six river stations. Results showed that the mean annual RWT negatively correlated with station elevation, which is consistent with previous analysis for river stations in the main stem of the Kupa River (Bonacci et al., 2008). However, the mean annual RWT presented no significant correlation with the drainage area listed in Table 1 (the coefficient of correlation $R=0.36$ ), which may be explained by the complex karst hydrological/hydrogeological behavior and weakly defined hydrological drainage areas (Bonacci and Andrić 2010).

The seasonal dynamics of water temperature $\left(T_{w}\right)$, air temperature $\left(T_{a}\right)$ and flow discharge $(Q)$ are presented in Fig. 6 through the climatological year. River flow mainly was generally higher in the spring and winter period for the six rivers, when air and water temperatures are lower. However, river flow is generally low when air temperatures are high, which may further intensify RWT increases. The response of $T_{w}$ to changes in $T_{a}$ is almost linear for the Donja Dobra River (Fig. 6(b)), the Donja Mrežnica River (Fig. 6(c)) and Korana River (Fig. 6(e)). Typically for the Donja Mrežnica River (Fig. 6(c)), 

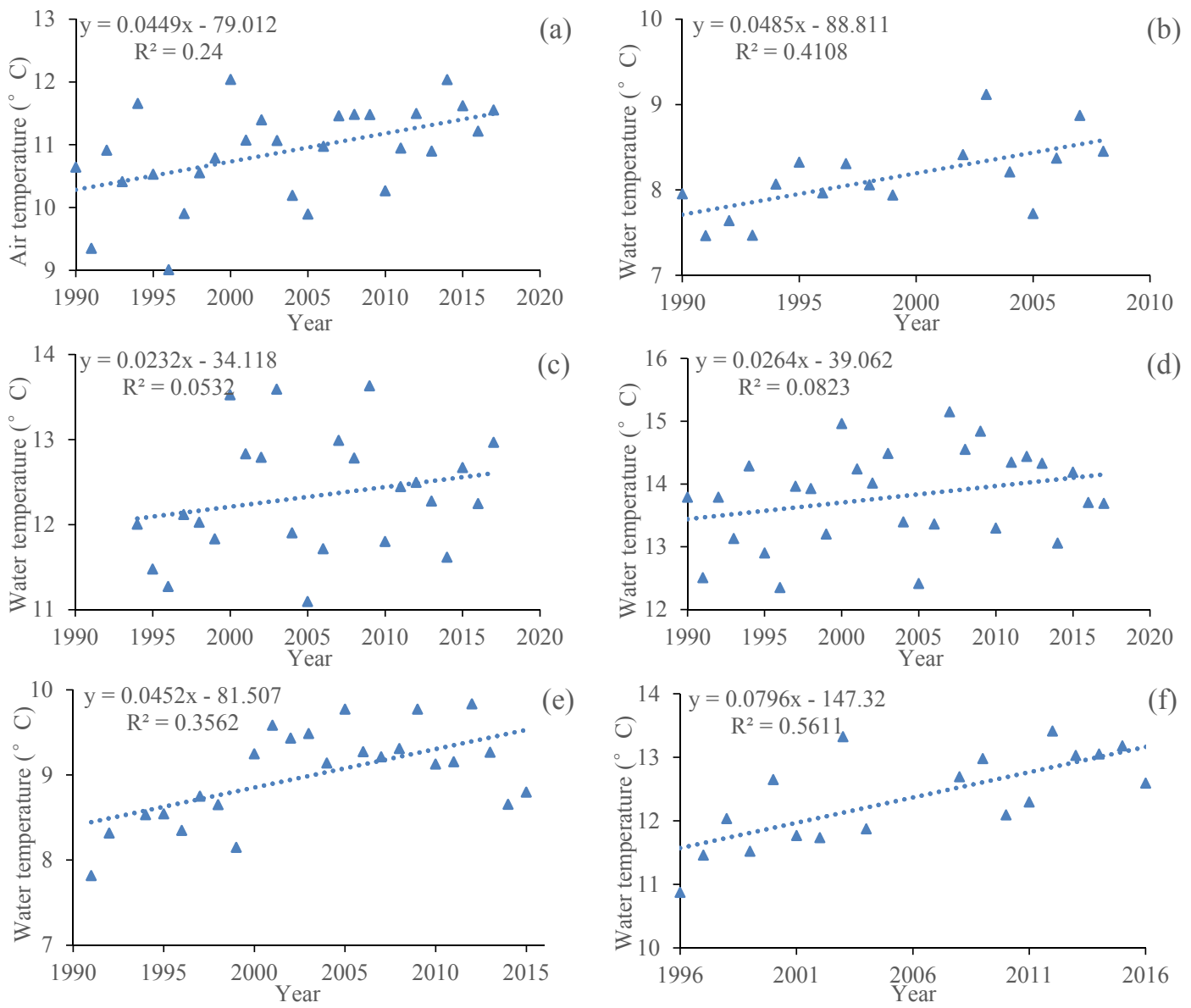

(e)
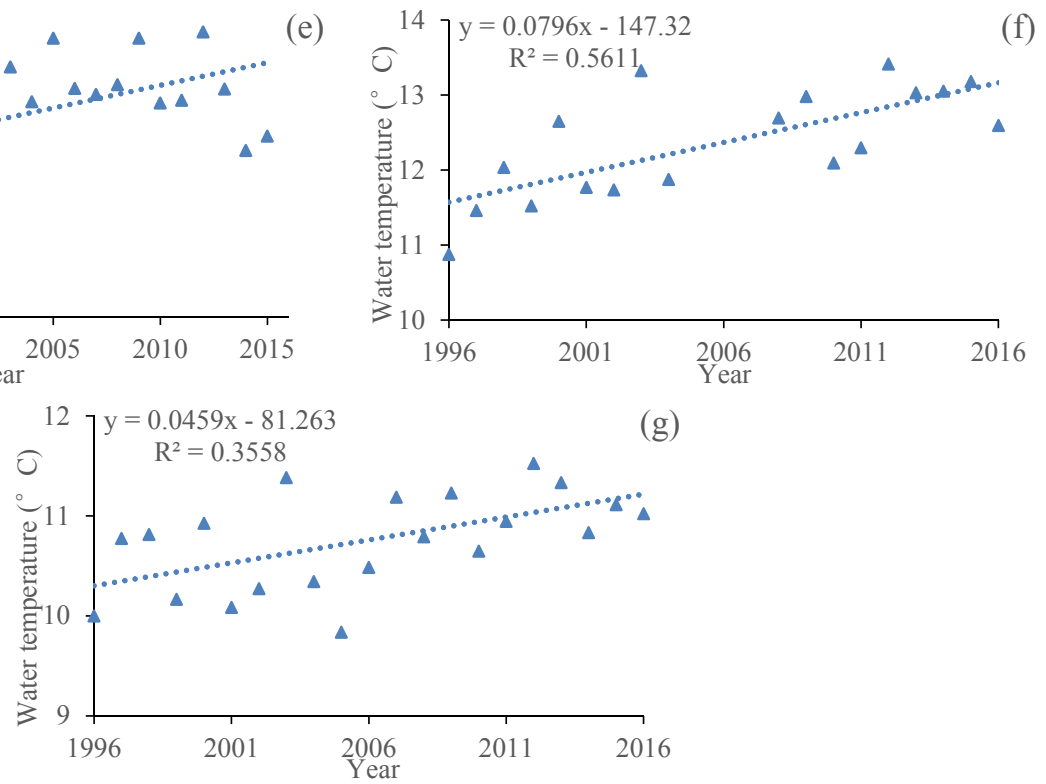

Fig. 2. Annual variations of $T_{a}$ and $T_{w}$ : (a) $T_{a}$ in Ogulin, (b) $T_{w}$ in Čabranka, (c) $T_{w}$ in Donja Dobra, (d) $T_{w}$ in Donja Mrežnica, (e) $T_{w}$ in Gornja Dobra, (f) $T_{w}$ in Korana and (g) $T_{w}$ in Slunjčica.

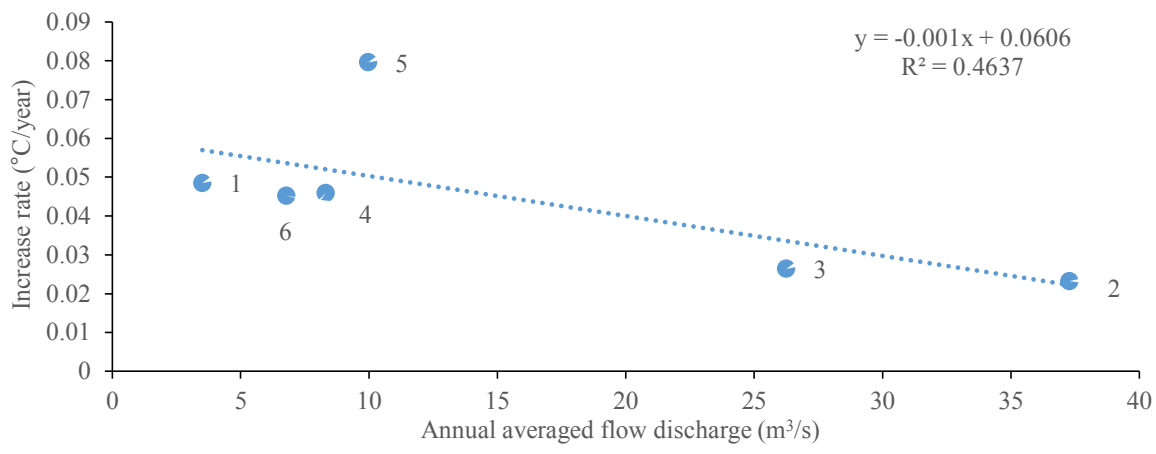

Fig. 3. Linear relationship between increase rate of river temperature and annual averaged flow discharge for the six rivers (1-Čabranka, 2Donja Dobra, 3-Donja Mrežnica, 4-Gornja Dobra, 5-Korana, 6- Slunjčica).

$T_{w}$ in the climatological year were larger than $T_{a}$ all the year round. The Čabranka River (Fig. 6(a)), Gornja Dobra River
(Fig. 6(d)), and Slunjčica River (Fig. 6(f)) presented a clear flattening of the seasonal pattern of $T_{w}$, especially in summer. 

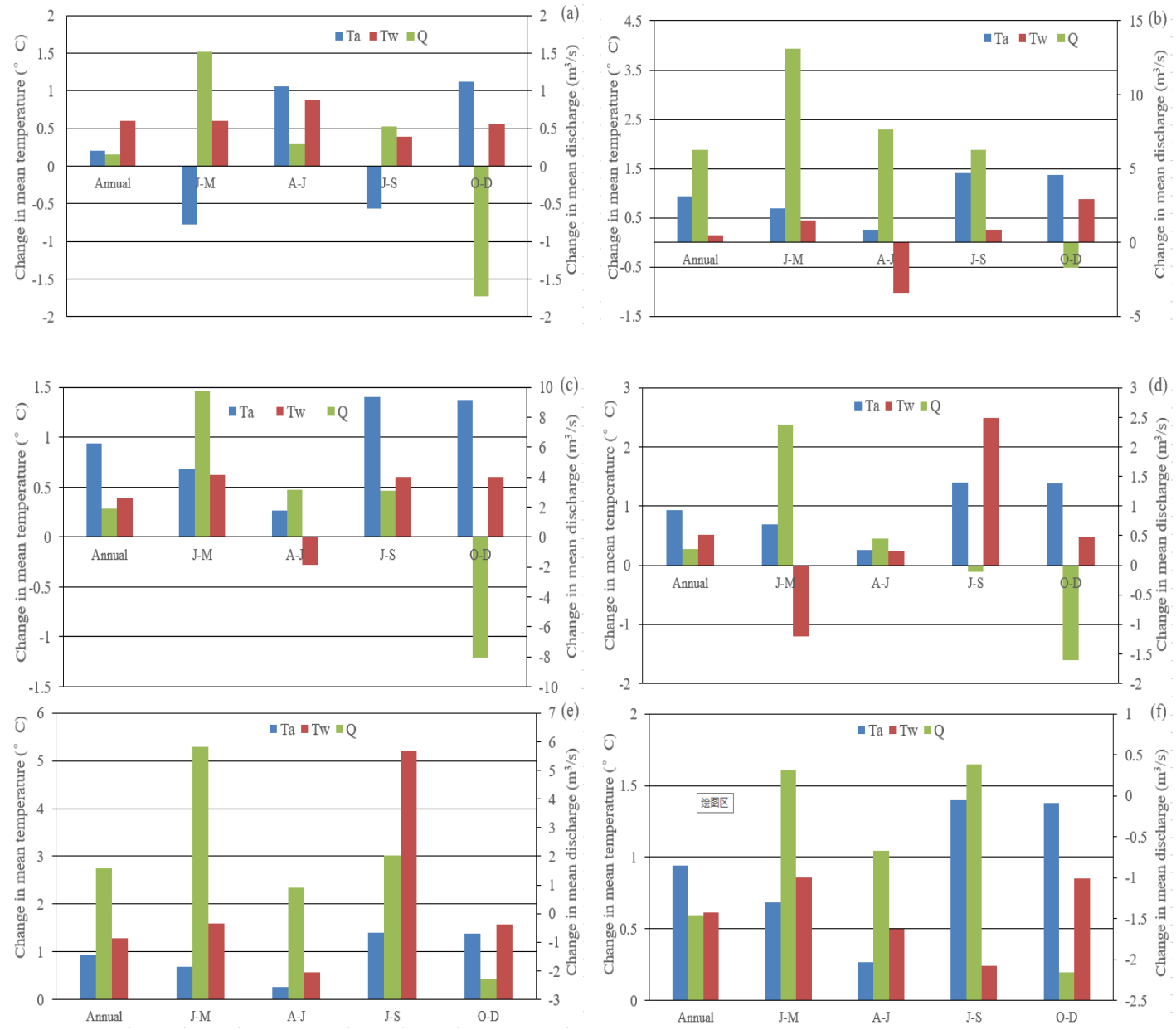

Fig. 4. Changes in $T_{a}, T_{w}$ and $Q$ between two sub-periods for annual and seasonal average values (J-M: January-March; A-J: April-June; JS: July-September; O-D: October-December): (a) Čabranka, (b) Donja Dobra, (c) Donja Mrežnica, (d) Gornja Dobra, (e) Korana, (f) Slunjčica.

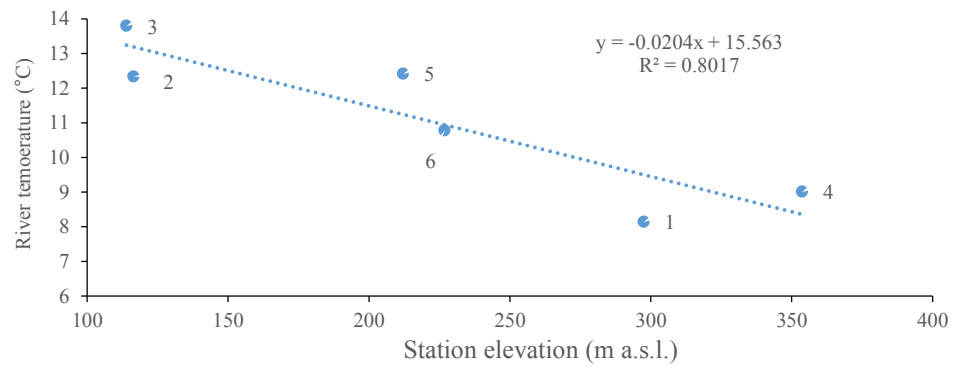

Fig. 5. Linear relationship between mean annual river temperature and station elevation for the studied river station in each river (1Čabranka, 2-Donja Dobra, 3-Donja Mrežnica, 4-Gornja Dobra, 5-Korana, 6- Slunjčica).

\section{Machine learning models for modeling daily river water temperature}

Models performance was similar but MLPNN model performed slightly better (Table 2), conforming the previous conclusion of Zhu et al. (2019). Compared to the models with only $T_{a}$ as input (version 1), combining $T_{a}$ and $Q$ in the version 2 models explained temporal variations of RWT more accurately (Table 2), especially for the Donja Dobra, Donja Mrežnica and Slunjčica rivers. For example, for the Slunjčica River, the MLPNN2 model decreased the RMSE and MAE values of MLPNN1 by $25.90 \%$ and $26.97 \%$ in the training phase, and $14.97 \%$ and $17.48 \%$ in the testing phase. By including DOY as model input, modeling performances dramatically improved (Table 2), which indicates that the seasonal component $D O Y$ plays an important role for RWT forecasting. For the Donja
Mrežnica River, the ANFIS2 model decreased the RMSE and MAE values of ANFIS1 by $18.58 \%$ and $23.00 \%$ in the training phase, and $21.30 \%$ and $25.64 \%$ in the testing phase. Generally, the two models performed well for RWT predictions. For model version 3 , in the testing phase, $R$ and $d$ values varied between 0.907 and 0.978 , and 0.951 and 0.989 respectively, and RMSE and MAE values ranged from 0.872 to $1.793^{\circ} \mathrm{C}$, and 0.627 to $1.435^{\circ} \mathrm{C}$. The modeling performances are comparable with that for the two river stations in the Drava River that had RMSE varying between 1.227 and $1.69^{\circ} \mathrm{C}$ (Zhu et al., 2019). Fig. 7 shows the variation of annual RMSE values (MLPNN3) for the whole modeling period in each river, which indicates that the annual RMSE values varied between years. The averaged RMSE values for the studied time periods were 1.077, 1.419, $1.285,1.356,1.583$ and $0.794^{\circ} \mathrm{C}$ for the Čabranka, Donja 

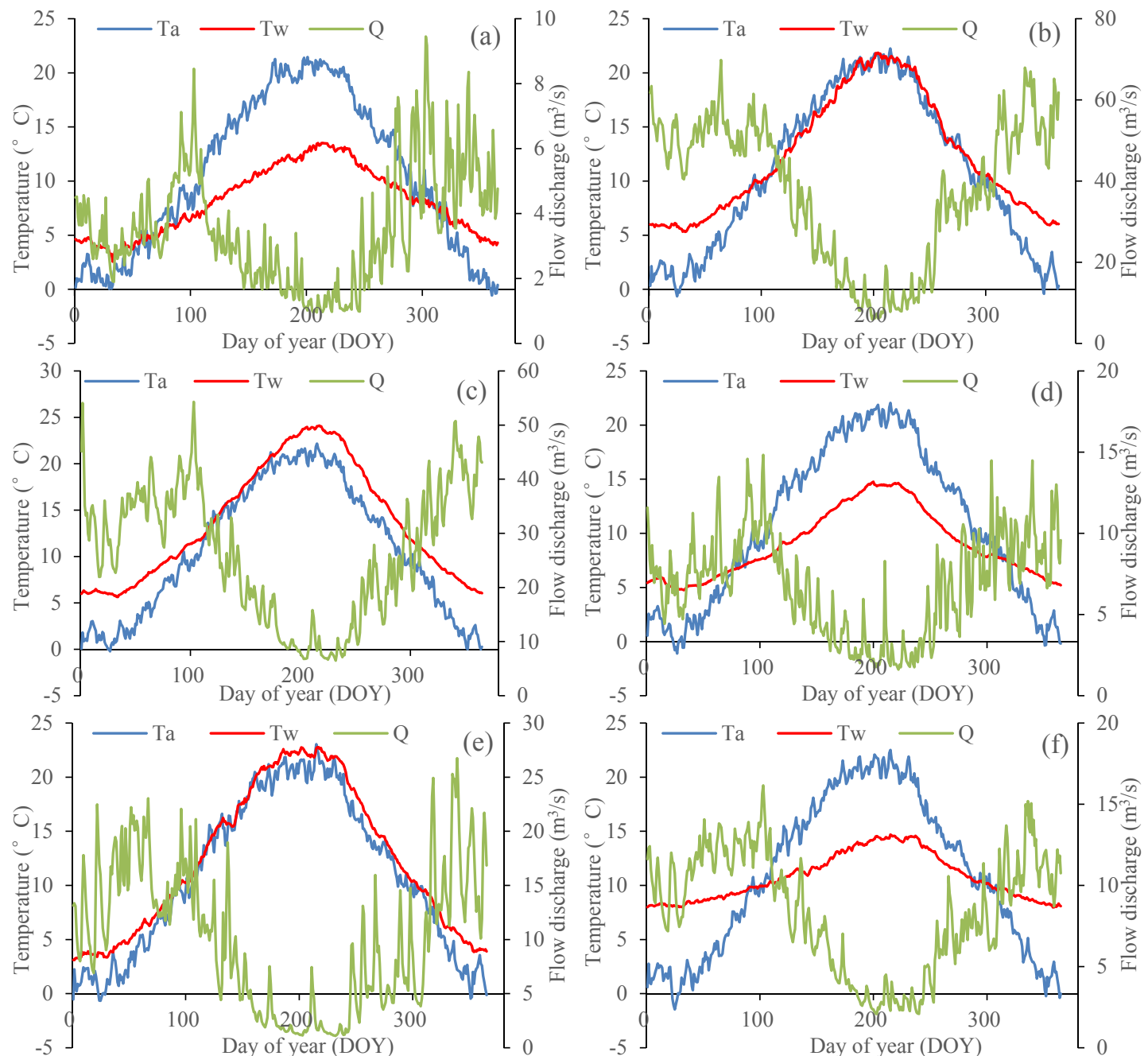

Fig. 6. Climatological (reference) year for the six rivers: (a) Čabranka, (b) Donja Dobra, (c) Donja Mrežnica, (d) Gornja Dobra, (e) Korana, (f) Slunjčica.

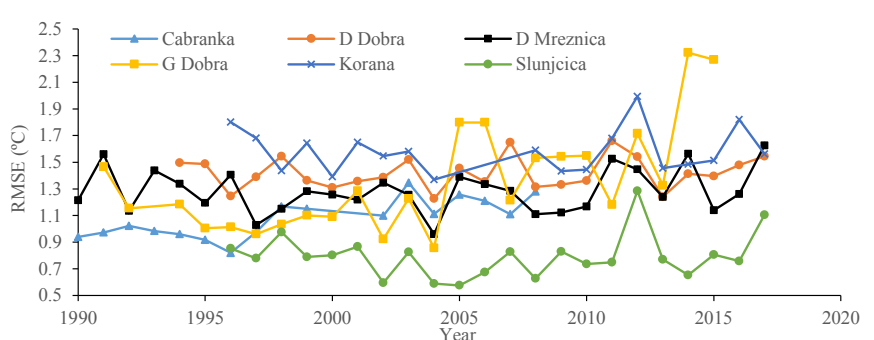

Fig. 7. Variation of annual RMSE values for the MLPNN3 models.

Dobra, Donja Mrežnica, Gornja Dobra, Korana, and Slunjčica respectively. The RMSE values compare reasonably with that in Jackson et al. (2018) $\left(1.57^{\circ} \mathrm{C}\right)$ and Sohrabi et al. (2017) $\left(1.25^{\circ} \mathrm{C}\right)$, and far better than that of Temizyurek and DadaserCelik (2018) $\left(2.10-2.64^{\circ} \mathrm{C}\right)$. Fig. 8 presents the modeling performances of the MLPNN3 for the climatological year at the six river stations. As is shown, the MLPNN3 model can well reproduce the seasonal dynamics of RWT in each river. The further test of modeling methods used in our previous research (Zhu et al., 2019) indicate that the models can be successfully applied for RWT forecasting for rivers characterized by different hydrological conditions. The models can be further coupled with regional climate models for future projections of RWT in the Kupa River watershed, which can help to inform water resources management in Croatia.

\section{CONCLUSIONS}

In this study, long term changes of RWT from six river stations in Kupa River watershed, Croatia were investigated. Results showed that RWT in the six studied river stations increased about $0.0232-0.0796^{\circ} \mathrm{C}$ per year with an increasing trend of air temperatures of $0.0449^{\circ} \mathrm{C}$ year ${ }^{-1}$, indicating an apparent warming trend. The results are comparable with long term observations for rivers in other regions (China, USA and Europe etc.). With an increase of $0.94^{\circ} \mathrm{C}$ for air temperature, the annual mean of RWT increased about $0.146-1.287^{\circ} \mathrm{C}$ in the two sub-periods (1996-2000 and 2011-2015). Results for different seasonal quarters revealed that temperature rises during the two sub-periods have not been constant for different periods of the year, and the contrasts between stations regarding temperature increases vary seasonally. In addition, MLPNN and ANFIS models were developed to predict daily RWT, using $T_{a}, Q$ and $D O Y$ as model inputs. Results showed that compared to the model version 1 with $T_{a}$ only, adding $Q$ better explained temporal variations of daily RWT. Using the three inputs as predictors $\left(T_{a}, Q\right.$ and the $\left.D O Y\right)$ yielded the best accuracy among all the developed models. RMSE and MAE values ranged from 0.872 to $1.793^{\circ} \mathrm{C}$, and 0.627 to $1.435^{\circ} \mathrm{C}$ respectively in the testing phase. Modeling results indicate that the developed models can well reproduce the seasonal dynamics of RWT. For further research, the models can be coupled with regional climate models for future projections of RWT. 
Long term variations of river temperature and the influence of air temperature and river discharge: case study of Kupa River watershed in Croatia

Table 2. Performances of different models in modelling water temperature $\left(T_{w}{ }^{\circ} \mathrm{C}\right)$ for the studied rivers in the Kupa River watershed.

\begin{tabular}{|c|c|c|c|c|c|c|c|c|c|}
\hline \multirow[t]{2}{*}{ River name } & \multirow[t]{2}{*}{ Model version } & \multicolumn{4}{|c|}{ Training } & & \multicolumn{3}{|c|}{ Testing } \\
\hline & & $R$ & $d$ & $R M S E\left({ }^{\circ} \mathrm{C}\right)$ & $\operatorname{MAE}\left({ }^{\circ} \mathrm{C}\right)$ & $R$ & $d$ & $R M S E\left({ }^{\circ} \mathrm{C}\right)$ & $M A E\left({ }^{\circ} \mathrm{C}\right)$ \\
\hline \multirow{5}{*}{ Čabranka } & MLPNN3 & 0.956 & 0.977 & 0.986 & 0.774 & 0.941 & 0.970 & 1.262 & 0.979 \\
\hline & MLPNN2 & 0.916 & 0.955 & 1.342 & 1.037 & 0.908 & 0.953 & 1.585 & 1.242 \\
\hline & MLPNN1 & 0.882 & 0.934 & 1.576 & 1.261 & 0.884 & 0.937 & 1.715 & 1.370 \\
\hline & ANFIS2 & 0.918 & 0.956 & 1.330 & 1.020 & 0.908 & 0.953 & 1.571 & 1.230 \\
\hline & ANFIS1 & 0.882 & 0.934 & 1.577 & 1.261 & 0.887 & 0.938 & 1.699 & 1.361 \\
\hline \multirow{5}{*}{ Donja Dobra } & MLPNN3 & 0.972 & 0.986 & 1.406 & 1.047 & 0.964 & 0.982 & 1.460 & 1.083 \\
\hline & MLPNN2 & 0.935 & 0.966 & 2.118 & 1.545 & 0.919 & 0.957 & 2.167 & 1.619 \\
\hline & ANFIS3 & 0.972 & 0.985 & 1.416 & 1.056 & 0.963 & 0.981 & 1.469 & 1.088 \\
\hline & ANFIS2 & 0.935 & 0.966 & 2.117 & 1.544 & 0.918 & 0.956 & 2.174 & 1.630 \\
\hline & ANFIS1 & 0.891 & 0.940 & 2.721 & 2.060 & 0.873 & 0.930 & 2.673 & 2.048 \\
\hline \multirow[t]{6}{*}{ Donja Mrežnica } & MLPNN3 & 0.980 & 0.990 & 1.274 & 0.990 & 0.978 & 0.989 & 1.334 & 1.040 \\
\hline & MLPNN2 & 0.923 & 0.959 & 2.479 & 1.828 & 0.923 & 0.959 & 2.450 & 1.801 \\
\hline & MLPNN1 & 0.882 & 0.934 & 3.042 & 2.374 & 0.873 & 0.930 & 3.115 & 2.417 \\
\hline & ANFIS3 & 0.980 & 0.990 & 1.297 & 1.002 & 0.978 & 0.989 & 1.334 & 1.034 \\
\hline & ANFIS2 & 0.923 & 0.959 & 2.476 & 1.828 & 0.923 & 0.959 & 2.453 & 1.798 \\
\hline & ANFIS1 & 0.882 & 0.934 & 3.041 & 2.374 & 0.873 & 0.930 & 3.117 & 2.418 \\
\hline \multirow{4}{*}{ Gornja Dobra } & MLPNN1 & 0.839 & 0.906 & 1.693 & 1.265 & 0.794 & 0.884 & 2.492 & 1.874 \\
\hline & ANFIS3 & 0.916 & 0.954 & 1.251 & 0.948 & 0.907 & 0.951 & 1.716 & 1.377 \\
\hline & ANFIS2 & 0.852 & 0.915 & 1.630 & 1.198 & 0.824 & 0.902 & 2.316 & 1.830 \\
\hline & ANFIS1 & 0.838 & 0.906 & 1.696 & 1.267 & 0.814 & 0.894 & 2.364 & 1.858 \\
\hline \multirow{6}{*}{ Korana } & MLPNN3 & 0.975 & 0.987 & 1.552 & 1.222 & 0.969 & 0.982 & 1.763 & 1.408 \\
\hline & MLPNN2 & 0.932 & 0.964 & 2.537 & 1.933 & 0.917 & 0.950 & 2.831 & 2.227 \\
\hline & MLPNN1 & 0.915 & 0.954 & 2.823 & 2.175 & 0.904 & 0.949 & 2.960 & 2.322 \\
\hline & ANFIS3 & 0.974 & 0.986 & 1.603 & 1.258 & 0.968 & 0.982 & 1.793 & 1.435 \\
\hline & ANFIS2 & 0.933 & 0.964 & 2.530 & 1.933 & 0.917 & 0.951 & 2.823 & 2.200 \\
\hline & ANFIS1 & 0.915 & 0.954 & 2.823 & 2.175 & 0.904 & 0.949 & 2.961 & 2.324 \\
\hline \multirow{6}{*}{ Slunjčica } & MLPNN3 & 0.952 & 0.975 & 0.767 & 0.580 & 0.938 & 0.956 & 0.882 & 0.655 \\
\hline & MLPNN2 & 0.922 & 0.958 & 0.967 & 0.715 & 0.909 & 0.939 & 1.028 & 0.765 \\
\hline & MLPNN1 & 0.853 & 0.915 & 1.305 & 0.979 & 0.851 & 0.920 & 1.209 & 0.927 \\
\hline & ANFIS3 & 0.951 & 0.974 & 0.771 & 0.582 & 0.939 & 0.957 & 0.872 & 0.627 \\
\hline & ANFIS2 & 0.922 & 0.958 & 0.965 & 0.715 & 0.909 & 0.939 & 1.024 & 0.764 \\
\hline & ANFIS1 & 0.853 & 0.915 & 1.305 & 0.978 & 0.852 & 0.920 & 1.208 & 0.926 \\
\hline
\end{tabular}
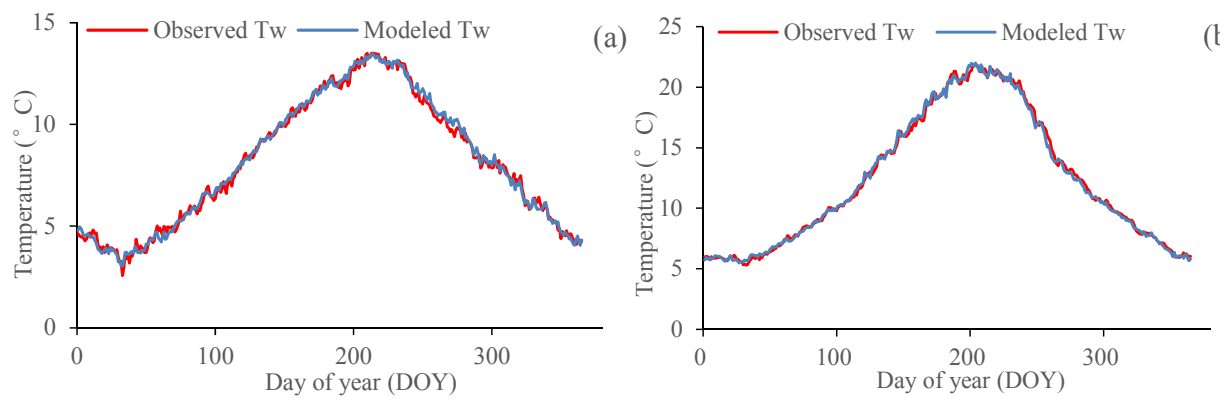

(b)
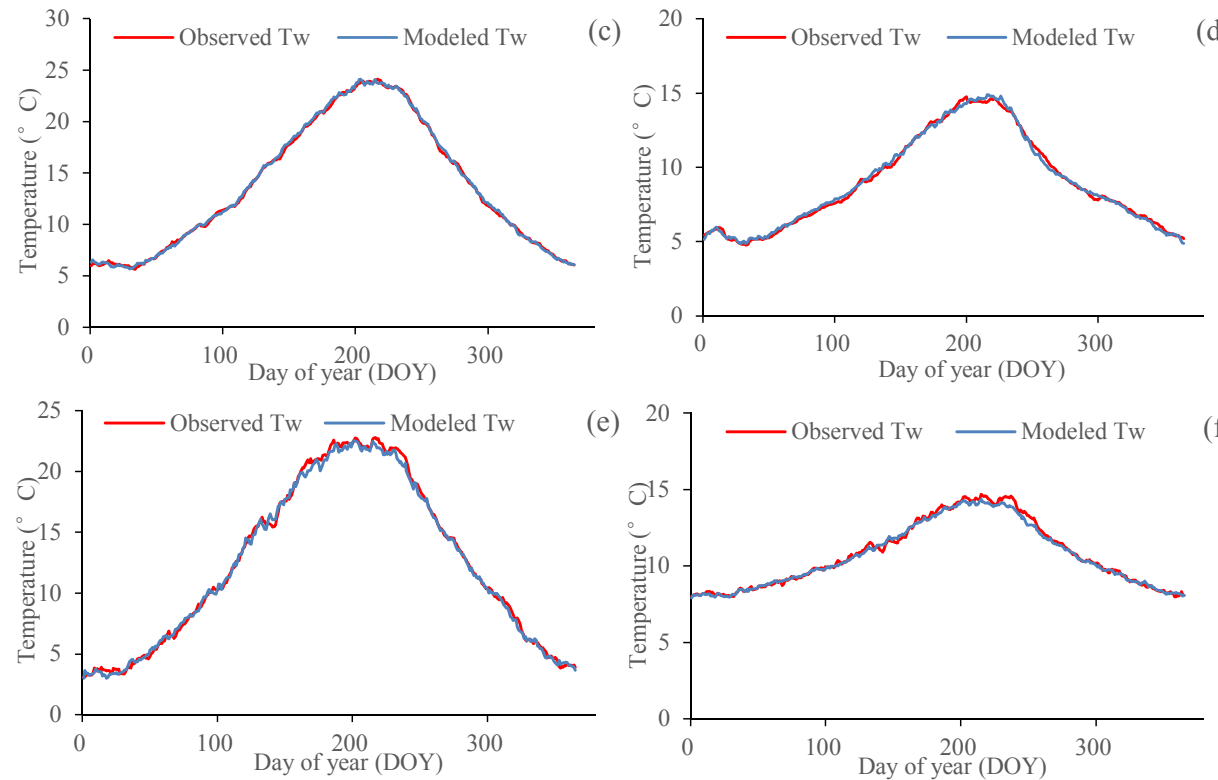

Fig. 8. Modeling performances of the MLPNN3 for the climatological year at the six rivers: (a) Čabranka, (b) Donja Dobra, (c) Donja Mrežnica, (d) Gornja Dobra, (e) Korana, and (f) Slunjčica. 
Acknowledgements. We acknowledge the Croatian Meteorological and Hydrological Service for providing the water temperature, air temperature and river flow discharge data used in this study. This work was jointly funded by the National Key R\&D Program of China (2018YFC0407203, 2016YFC0401506), China Postdoctoral Science Foundation (2018M640499) and the research project from Nanjing Hydraulic Research Institute (Y118009).

\section{REFERENCES}

Albek, M., Albek, E., 2009. Stream temperature trends in Turkey. Clean Soil Air \& Water, 37, 142-149.

Ayllón, D., Almodóvar, A., Nicola, G.G., Parra, I., Elvira, B., 2012. A new biological indicator to assess the ecological status of Mediterranean trout type streams. Ecological Indicators, 20, 295-303.

Bonacci, O., Andrić, I., 2010. Impact of an inter-basin water transfer and reservoir operation on a karst open streamflow hydrological regime: an example from the Dinaric karst (Croatia). Hydrological Processes, 24, 3852-3863.

Bonacci, O., Trninić, D., Roje-Bonacci, T., 2008. Analysis of the water temperature regime of the Danube and its tributaries in Croatia. Hydrological Processes, 22, 1014-1021.

Chen, D., Hu, M., Guo, Y., Dahlgren, R.A., 2016. Changes in river water temperature between 1980 and 2012 in Yongan watershed, eastern China: magnitude, drivers and models. Journal of Hydrology, 533, 191-199.

Cingi, S., Keinänen, M., Vuorinen, P.J., 2010. Elevated water temperature impairs fertilization and embryonic development of whitefish Coregonus lavaretus. Journal of Fish Biology, 76, 502-521.

Cox, B.A., Whitehead, P.G., 2009. Impacts of climate change scenarios on dissolved oxygen in the River Thames, UK. Hydrology Research, 40, 138-152.

DeWeber, J.T., Wagner, T., 2014. A regional neural network ensemble for predicting mean daily river water temperature. Journal of Hydrology, 517, 187-200.

Feng, M., Zolezzi, G., Pusch, M., 2018. Effects of thermopeaking on the thermal response of alpine river systems to heatwaves. Science of the Total Environment, 612, 1266-1275.

Frančišković-Bilinski, S., Bhattacharya, A.K., Bilinski, H., Bhattacharya, B.D., Mitra, A., Sarkar, S.K., 2012. Fluvial geomorphology of the Kupa River drainage basin, Croatia: a perspective of its application in river management and pollution studies. Zeitschrift für Geomorphologie, 56, 93-119.

Fullerton, A.H., Torgersen, C.E., Lawler, J.J., Steel, E.A., Ebersole, J.L., Lee, S.Y., 2018. Longitudinal thermal heterogeneity in rivers and refugia for coldwater species: effects of scale and climate change. Aquatic Sciences, 80, 3.

Gooseff, M.M., Strzepek, K., Chapra, S.C., 2005. Modeling the potential effects of climate change on water temperature downstream of a shallow reservoir, lower Madison River, MT. Climatic Change, 68, 331-353.

Hadzima-Nyarko, M., Rabi, A., Šperac, M., 2014. Implementation of artificial neural networks in modeling the water-air temperature relationship of the river Drava. Water Resources Management, 28, 1379-1394.

Hardenbicker, P., Viergutz, C., Becker, A., Kirchesch, V., Nilson, E., Fischer, H., 2017. Water temperature increases in the river Rhine in response to climate change. Regional Environmental Change, 17, 299-308.

Heddam, S., 2016. New modelling strategy based on radial basis function neural network (RBFNN) for predicting dissolved oxygen concentration using the components of the Gregorian calendar as inputs: case study of Clackamas River, Oregon, USA. Modeling Earth Systems \& Environment, 2, 1-5.
Heddam, S., Kisi, O., 2017. Extreme learning machines: a new approach for modeling dissolved oxygen (DO) concentration with and without water quality variables as predictors. Environmental Science and Pollution Research, 24, 16702-16724.

Isaak, D.J., Wollrab, S., Horan, D., Chandler, G., 2012. Climate change effects on stream and river temperatures across the northwest U.S. from 1980-2009 and implications for salmonid fishes.

Climatic

Change, 113, 499-524.

Jackson, F.L., Fryer, R.J., Hannah, D.M., Millar, C.P., Malcolm, I.A., 2018. A spatio-temporal statistical model of maximum daily river temperatures to inform the management of Scotland's Atlantic salmon rivers under climate change. Science of the Total Environment, 621, 1543-1558.

Kim, J.H., Park, H.J., Hwang, I.K., Han, J.M., Kim, D.H., Oh, C.W., Lee, J.S., Kang, J.C., 2017. Toxic effects of juvenile sablefish, Anoplopoma fimbria by ammonia exposure at different water temperature. Environmental Toxicology and Pharmacology, 54, 169-176.

Leblanc, R.T., Brown, R.D., Fitzgibbon, J.E., 1997. Modeling the effects of land use change on the water temperature in unregulated urban streams. Journal of Environmental Management, 49, 445-469.

Lepori, F., Pozzoni, M., Pera, S., 2014. What drives warming trends in streams? A case study from the Alpine Foothills. River Research and Applications, 31, 663-675.

Markovic, D., Scharfenberger, U., Schmutz, S., Pletterbauer, F., Wolter, C., 2013. Variability and alterations of water temperatures across the Elbe and Danube River Basins. Climatic Change, 119, 375-389.

Moatar, F., Gailhard, J., 2006. Water temperature behaviour in the River Loire since 1976 and 1881. Comptes Rendus Geoscience, 338, 319-328.

Null, S.E., Viers, J.H., Deas, M.L., Tanaka, S.K., Mount, J.F., 2013. Stream temperature sensitivity to climate warming in California's Sierra Nevada: impacts to coldwater habitat. Climatic Change, 116, 149-170.

Orr, H.G., Simpson, G.L., des Clers, S., Watts, G., Hughes, M., Hannaford, J., Dunbar, M.J., Laizé, C.L.R., Wilby, R.L., Battarbee, R.W., Evans, R., 2015. Detecting changing river temperatures in England and Wales. Hydrological Processes, 29, 752766.

Pekárová, P., Miklánek, P., Halmová, D., Onderka, M., Pekár, J., Kučárová, K., Liová, S., Škoda, P., 2011. Long-term trend and multi-annual variability of water temperature in the pristine Bela River basin (Slovakia). Journal of Hydrology, 400, 333340.

Piotrowski, A.P., Napiorkowski, M.J., Napiorkowski, J.J., Osuch, M., 2015. Comparing various artificial neural network types for water temperature prediction in rivers. Journal of Hydrology, 529, 302-315.

Rice, K.C., Jastram, J.D., 2015. Rising air and stream-water temperatures in Chesapeake Bay region, USA. Climatic Change, $128,127-138$.

Schär, C., Vidale, P.L., Lüthi, D., Frei, C., Häberli, C., Liniger, M.A., Appenzeller, C., 2004. The role of increasing temperature variability in European summer heatwaves. Nature, 427, 332336.

Sohrabi, M.M., Benjankar, R., Tonina, D., Wenger, S.J., Isaak, D.J., 2017. Estimation of daily stream water temperatures with a Bayesian regression approach. Hydrological Processes, 31, 1719-1733.

Temizyurek, M., Dadaser-Celik, F., 2018. Modelling the effects of meteorological parameters on water temperature using artificial neural networks. Water Science and Technology, 77, 17241733. 
Toffolon, M., Piccolroaz, S., 2015. A hybrid model for river water temperature as a function of air temperature and discharge. Environmental Research Letters, 10, 114011.

van Vliet, M.T.H., Ludwig, F., Zwolsman, J.J.G., Weedon, G.P., Kabat, P., 2011. Global river temperatures and sensitivity to atmospheric warming and changes in river flow. Water Resources Research, 47, 247-255.

van Vliet, M.T.H., Franssen, W.H.P., Yearsley, J.R., Ludwig, F., Haddeland, I., Lettenmaier, D.P., Kabat, P., 2013. Global river discharge and water temperature under climate change. Global Environmental Change, 23, 450-464.

Webb, B.W., Clack, P.D., Walling, D.E., 2003. Water-air temperature relationships in a Devon river system and the role of flow. Hydrological Processes, 17, 3069-3084.
Žganec, K., 2012. The effects of water diversion and climate change on hydrological alteration and temperature regime of karst rivers in central Croatia. Environmental Monitoring and Assessment, 184, 5705-5723.

Zhu, S., Heddam, S., Nyarko, E.K., Hadzima-Nyarko, M., Piccolroaz, S., Wu, S., 2019. Modeling daily water temperature for rivers: comparison between adaptive neuro-fuzzy inference systems and artificial neural networks models. Environmental Science and Pollution Research, 26, 402-420.

Received 17 January 2019 Accepted 13 March 2019 